\title{
IDENTIFIKASI EFEK HEATING RATE TERHADAP LAJU KINETIKA REAKSI PIROLISIS KAYU MAHONI DENGAN THERMAL ANALYSIS DAN TERMOGRAVIMETRY
}

\author{
Widya Wijayanti \\ Dosen \\ Universitas Brawijaya \\ Jurusan Teknik Mesin \\ widya_dinata@ub.ac.id
}

\begin{abstract}
The study was conducted to investigate the biomass pyrolysis using mahogany wood as the feedstock. Chemically, mahogany wood contained complex biomass compounds, consisting of cellulose, hemicellulose, and lignin. Each biomass compound had its degradation at a certain temperature. Therefore, their compounds will be pyrolyzed at some different temperatures to understand the certain one. In the experiment, the biomass was hydrolyzed based on the temperature differences from room temperature to a temperature around $1000^{\circ} \mathrm{C}(1273 \mathrm{~K})$. We identified pyrolysis kinetic rate and measured some appropriate pyrolysis temperatures to accomplish the pyrolysis process. Afterward, the investigation of its thermal degradation used Thermal Analysis and Thermogravimetric (TGA) analysis. It would be obtained the estimation of energy needed to obtain a mathematical equation determined by the dependencies of the pyrolysis temperature by using LINSEIS STA Platinum Series. The mathematical equation was gained by using the temperature difference profiles (differential thermal analysis-DTA) and the biomass weight loss (difference thermogravimetry-DTG) by means of TGA. It was measured under the inert condition without Oxygen at the heating rate of $400^{\circ} \mathrm{C} / \mathrm{h}$ and $800^{\circ} \mathrm{C} / \mathrm{h}$. By using order-1 differential equations, the activation energy, and preexponential factors also were determined in the mathematical equation of the kinetic reaction rate equation as $k_{1}=7.9033$ for a heating rate of $400^{\circ} \mathrm{C} / \mathrm{h}$ and $k_{2}=9.7745$ for heating rate $800^{\circ} \mathrm{C} / \mathrm{h}$.
\end{abstract}

Keywords : pyrolysis, heating rate, thermal analysis, termogravimetry

\section{PENDAHULUAN}

Pirolisis adalah proses konversi termokimia yang dapat digunakan untuk membentuk biomas menjadi bahan bakar gas dan cair, serta padat. Proses ini juga penting sebagai langkah awal proses pembakaran dan gasifikasi. Oleh karena itu, kedepannya, perlu diteliti pemahaman tentang kinetika pirolisis yang menyangkut desain piroliser dan proses produksi bahan bakar hasil pirolisis pada aplikasi konversi biomasa ini. Selain itu, proses pirolisis ini juga dapat menggunakan berbagai macam produk kimia sebagai feedstock/bahan bakunya. Sehingga, perlu dipelajari lebih lanjut tentang mekanisme dekomposisi bahan bakunya pada pirolisis ini untuk memperbaiki transformasi biomasa pada aplikasi produksi biofuel, produksi bahan kimia, dan biomaterial.

Untuk mengetahui kondisi operasi proses yang optimal, maka mekanisme pirolisis dapat dianalisa dengan cara melihat laju perpindahan panasnya (heating rate) dan laju kecepatan (kinetika) reaksinya. Laju perpindahan panas dan prediksi laju kecepatan reaksinya pada fixed bed telah diteliti [1-4], namun devolatilasi yang merupakan dasar pemahaman perpindahan masa dari pirolisis sendiri belum diamati. Oleh karena itu, 
dengan teknik analisa panas dan perpindahan masa yang menyangkut kecepatan reaksi akibat perpindahan panas dapat diketahui dengan cara yang sederhana. Selain itu, perilaku perpindahan panas dan masanya langsung diketahui, tidak dengan cara memproses pirolisis secara langsung, tapi dengan mengambil sedikit sampel biomasa untuk diuji pada thermogravimetric analysis (TGA) and derivative thermogravimetry (DTG). Secara umum, TGA sering digunakan untuk melihat pengaruh temperatur selama proses pirolisis berlangsung. Karakteristik pengurangan masa biomasa selama proses berlangsung dapat diamati pada analisa ini. Metode ini memiliki kemampuan untuk mengungkapkan kompleksitas proses dalam bentuk ketergantungan fungsional dari energi aktivasi pada tingkat konversi.

Analisa termal dapat didefinisikan sebagai pengukuran sifat-sifat fisik dan kimia material sebagai fungsi dari temperatur. Penggunaan analisa termal pada zat padat (solid) telah demikian luas dan bervariasi, termasuk studi reaksi keadaan padat seperti pada pirolisis biomasa, dekomposisi termal dan transisi fasanya, serta penentuan diagram fasanya. Kebanyakan padatan bersifat 'aktif secara termal' dan sifat ini menjadi dasar analisa zat padat menggunakan analisa termal [5].

Pada penelitian ini, akan diteliti pirolisis biomasa dengan menggunakan kayu mahoni. Secara kimia, kayu mahoni tersusun atas senyawa yang kompleks, yaitu selulosa, hemiselulosa, dan lignin. Degradasi termal atas masing-masing senyawa secara individu dapat berlangsung secara homogen dengan temperatur dekomposisi tertentu. Tetapi, untuk campuran senyawa yang kompleks, dilakukan pendekatan yang berbeda untuk menggambarkan degradasi termal menggunakan analisis TGA dan metode non-isotermal. Adapun pendekatan degradasi termal yang digunakan adalah persamaan integral dan diferensial dengan memperkirakan energi aktivasi yang membutuhkan pendekatan matematika untuk dependensi temperatur. Namun, ketika faktor pra-eksponensial dan urutan reaksi harus diperkirakan, maka wajib untuk menggunakan pendekatan untuk komposisi dependensi. Metode-metode ini memiliki kemampuan untuk mengungkapkan kompleksitas proses dalam bentuk ketergantungan fungsional dari energi aktivasi pada tingkat konversi. Penerapan metode bebasmodel sangat dianjurkan untuk mendapatkan deskripsi kinetik yang dapat diandalkan dari proses yang diteliti. Asumsi dasar dari model ini adalah bahwa laju reaksi untuk tingkat konversi hanya bergantung pada suhu. Model-model ini tidak memerlukan pengetahuan sebelumnya tentang mekanisme reaksi untuk degradasi termal biomassa. Dengan demikian, dalam reaksi heterogen pada biomasa, ada kemungkinan bahwa kejadian pengendali laju kinetik mungkin adalah terjadinya transformasi fisik yang bergantung pada suhu yang tidak tergantung massa biomasa, menjelaskan variasi energi aktifasi dengan laju pemanasan dan sesuai dengan fenomena yang ada. Untuk membangun gambaran penerapan energi biomasa ini, profil pirolisis TGA dan DTG ditentukan di bawah kondisi inert pada heating rate yang berbeda. Pada penelitian ini nanti, data eksperimen akan dilengkapi dengan variasi heating rate dan temperatur pirolisis. Dengan menggunakan persamaan diferensial orde-1, energi aktivasi dan faktor pra-eksponensial akan dihitung beserta variasi temperatur dan heating rate.

Heating rate sangat mempengaruhi produk yield dari proses pirolisis. Pada heating rate yang tinggi, mayoritas produk yang dihasilkan dalam bentuk gas dan tar, sebaliknya pada heating rate rendah, mayoritas produk adalah produk padat (char). Pada real pilot plant, efek dari fast pirolisis dan slow pirolisis yang menggunakan perbedaan heating rate sudah diteliti [6]. Pada penelitian tersebut, persamaan laju kinetik yang digunakan masih memakai model penelitian peneliti sebelumnya. Oleh karena itu, dengan peralatan analisa termal yang modern dan otomatik, dimungkinkan untuk karakterisasi material dengan TGA dan DTA menggunakan alat yang sama dengan beberapa model yang memungkinkan pengukuran TGA dan DTA secara simultan. Oleh karena itu, setelah diteliti performance dari proses pirolisis [7-8], maka penelitian kali ini akan melihat efek heating rate yang akan mempengaruhi laju kinetika reaksi proses pirolisis dengan menggunakan alat Thermal Analysis dan Termogravimetry. Dari TGA tersebut, akan dapat diamati penurunan masa solid yield yang menunjukkan perubahan masa biomasa selama proses pirolisis menjadi produk-produknya; tar, gas, dan char, meskipun pada TGA tidak dapat diamati produk gas dan tar tersebut. Selain penurunan masa, perubahan temperatur yang akan mempengaruhi perubahan masa akibat dekomposisi kayu mahoni juga dapat diidentifikasi. Selanjutnya, dari kedua kondisi perubahan tersebut dapat diidentifikasi laju kinetika reaksinya. Dari persamaan laju kinetika reaksi yang didapat, maka akan dapat diprediksi perubahan masa (solid yield) biomasa secara teoritis.

\section{METODE DAN BAHAN}

\subsection{ALAT DAN BAHAN}

Bahan yang digunakan untuk diamati pirolisis (dekomposisi termalnya) pada penelitian ini adalah serbuk kayu mahoni. Sebelum diproses pirolisis pada TGA, serbuk kayu mahoni dipanaskan terlebih dahulu 
selama 3 jam dalam oven untuk meminimalisasi kadar airnya hingga 2\%. Kayu mahoni dipanaskan pada suhu $100^{\circ} \mathrm{C}$.

Sedangkan instrumen untuk menganalisa kinetika reaksi pada proses pirolisis ini dilakukan dengan menggunakan teknik analisa termal. Ada dua jenis teknik analisa termal utama yang digunakan dalam penelitian ini adalah analisa termogravimetrik (TGA), yang secara otomatis merekam perubahan berat sampel sebagai fungsi dari suhu maupun waktu, dan analisa diferensial termal (DTA) yang mengukur perbedaan suhu, $\Delta \mathrm{T}$, antara sampel dengan material referen yang inert sebagai fungsi dari suhu.

TGA digunakan untuk menentukan stabilitas termal kayu mahoni dan fraksi komponen volatile dengan menghitung perubahan berat yang dihubungkan dengan perubahan temperatur. Kurva yang dihasilkan pada analisis termogavimetrik (TGA) ini nanti adalah perubahan massa biomasa kayu mahoni terhadap temperatur sebagai kurva TG. Kurva TG merupakan plot dari penurunan massa yang diplot pada sumbu y dan perubahan temperatur yang direkam pada sumbu x. Selain itu, dapat juga diplotting perubahan massa biomasa terhadap perubahan waktunya (DTG).

Pada penelitian ini, perubahan masa kayu mahoni diamati dengan mengukur perubahan berat kayu mahoni setiap waktu. Untuk mengkondisikan dekomposisi termal yang terjadi adalah proses pirolisis, maka gas Nitrogen sebagai gas inert untuk menghindari terjadinya pembakaran oleh udara dimasukkan ke dalam TGA. Adapun jenis alat TGA yang digunakan dalam penelitian ini ber-merk LINSEIS STA Platinum Series dengan skema eksperimental TGA yang dapat dilihat pada Gambar 1.
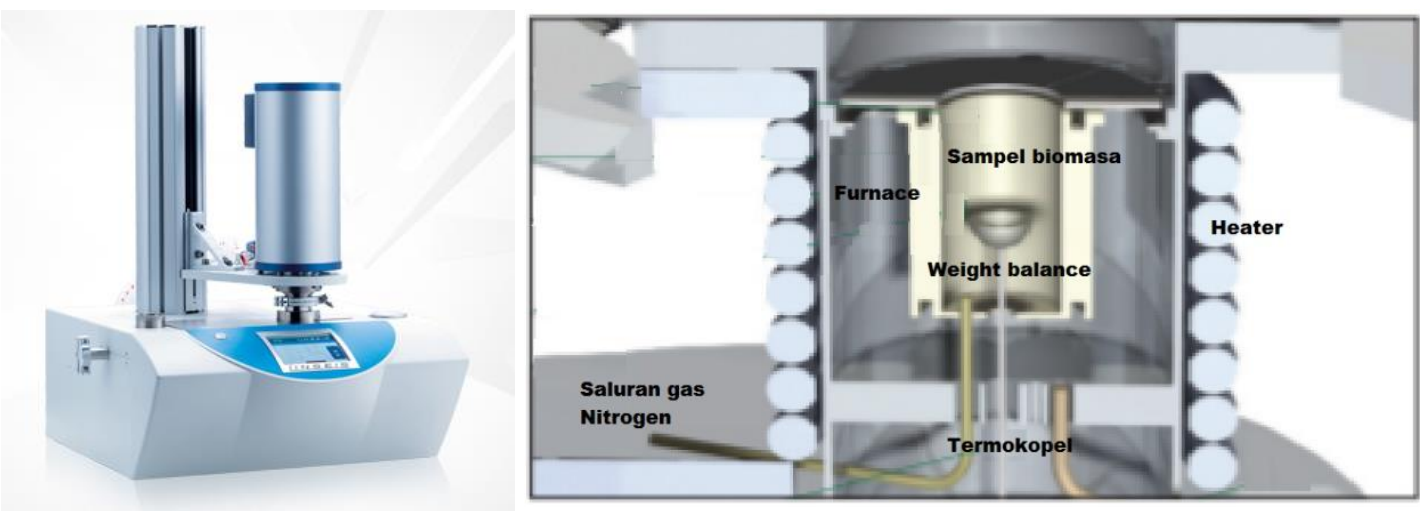

Gambar 1. TGA dan skema komponen utama TGA

Dari gambar 1 tersebut dapat dilihat bahwa komponen utama TGA terdiri atas:

\section{Weight balance}

Komponen ini disertai dengan termokopel yang disebut dengan thermobalance yang terdiri atas timbangan (weight balance) yang terbagi atas 2 jenis timbangan, yaitu timbangan vertikal dan timbangan horisontal. Timbangan vertikal memiliki suatu tempat sampel yang bergantung pada timbangan yang diperlukan untuk mengkalibrasi instrumen dari efek buoyancy pada variasi densitas gas dengan temperatur, seperti variasi jenis gas. Timbangan vertikal merupakan pelengkap timbangan horisontal karena biasanya tidak mempunyai tempat referensi dan tidak dapat digunakan untuk pengukuran DTA atau DSC dengan benar. Sedangkan timbangan horizontal memiliki dua tempat (sampel dan referensi) dan dapat digunakan untuk pegukuran DTA dan DSC. Instrumen ini bebas dari efek buoyancy, tetapi memerlukan kalibrasi untuk ekspansi perbedaan panas neraca timbangan. Adapun komponen berikutnya adalah

\section{Furnace}

Merupakan tempat sampel biomasa yang akan dipirolisis, yang disebut dengan furnace. Furnace dan sistem kontrol didesain untuk menghasilkan pemanasan yang linear selama proses pirolisis. Range temperatur pada furnace ini dibuat tetap pada temperatur tetap. Range temperatur pada TGA umumnya berkisar antara $-150^{\circ} \mathrm{C}$ hingga $2000^{\circ} \mathrm{C}$. Range temperatur dari furnace biasanya tergantung pada jenis pemanas yang digunakan. Sedangkan laju rata-rata pemanasan atau pendinginan pada furnace dapat dipilih antara 0$200^{\circ} \mathrm{C} /$ menit.

\section{Termokontrol}

Pengukur dan kontrol temperatur dilakukan menggunakan termokopel. Jenis termokopel yang digunakan pada temperatur diatas $1000^{\circ} \mathrm{C}$ yaitu chromal-alumel, sedangkan $\mathrm{Pt} /(\mathrm{Pt}-10 \% \mathrm{Rh})$ digunakan untuk 
temperatur diatas $1750^{\circ} \mathrm{C}$. Pada penelitian ini digunakan jenis termokopel Pt. Temperatur dikontrol atau divariasikan menggunakan program kontroler dengan menggunakan termokopel.

\subsection{Prosedur Pengujian}

Mula-mula serbuk kayu mahoni disaring dengan menggunakan mesh dengan ukuran $10 \mu \mathrm{m}$. Selanjutnya dimasukkan ke dalam oven dengan temperatur pengeringan antara $100^{\circ} \mathrm{C}-110^{\circ} \mathrm{C}$ selama $3 \mathrm{jam}$. Hal ini dilakukan untuk mengurangi kadar air yang terkandung di dalam serbuk kayu sampai serbuk kayu mahoni mencapai kadar air 0\%-2\%. Adapun pengujian kadar air dilakukan dengan menggunakan moisture analyzer Sartorius MA 30. Setelah dilakukan pengujian kadar air, maka dilakukan penimbangan massa dari serbuk kayu mahoni seberat 20 gram. Setelah itu, sampel kayu mahoni seberat 20 gram tersebut dimasukkan ke dalam TGA dan dilakukan pengujian. Awalnya, heater dipanaskan. Termokopel ditempatkan dan dipasang secara langsung pada sampel. Selanjutnya, temperatur heater meningkat diikuti dengan peningkatan temperatur biomasa. Temperatur pemanasan untuk heater pada saat proses pirolisis yaitu berkisar antara $250^{\circ} \mathrm{C}-1000^{\circ} \mathrm{C}$ dengan menggunakan variasi heating rate $400^{\circ} \mathrm{C} / \mathrm{jam}$ dan $800^{\circ} \mathrm{C} / \mathrm{jam}$. Data hasil pengujian proses pirolisis ini adalah perubahan masa biomasa selama proses pirolisis, perubahan kecepatan perubahan masa (DTG), serta perubahan termal selama proses pirolisis (DTA). Dari hasil tersebut akan didapatkan rumusan persamaan laju kinetika reaksinya selama proses pirolisis.

\section{HASIL DAN DISKUSI}

Dari penelitian ini didapatkan data berupa perubahan masa biomasa selama proses pirolisis. Data tersebut menunjukkan pengurangan massa pada proses pirolisis dengan menggunakan laju pemanasan (heating rate) $400{ }^{\circ} \mathrm{C} / \mathrm{jam}$ dan $800{ }^{\circ} \mathrm{C} / \mathrm{jam}$. Data hasil pengukuran perubahan masa kayu mahoni dapar dilihat pada Gambar 2.

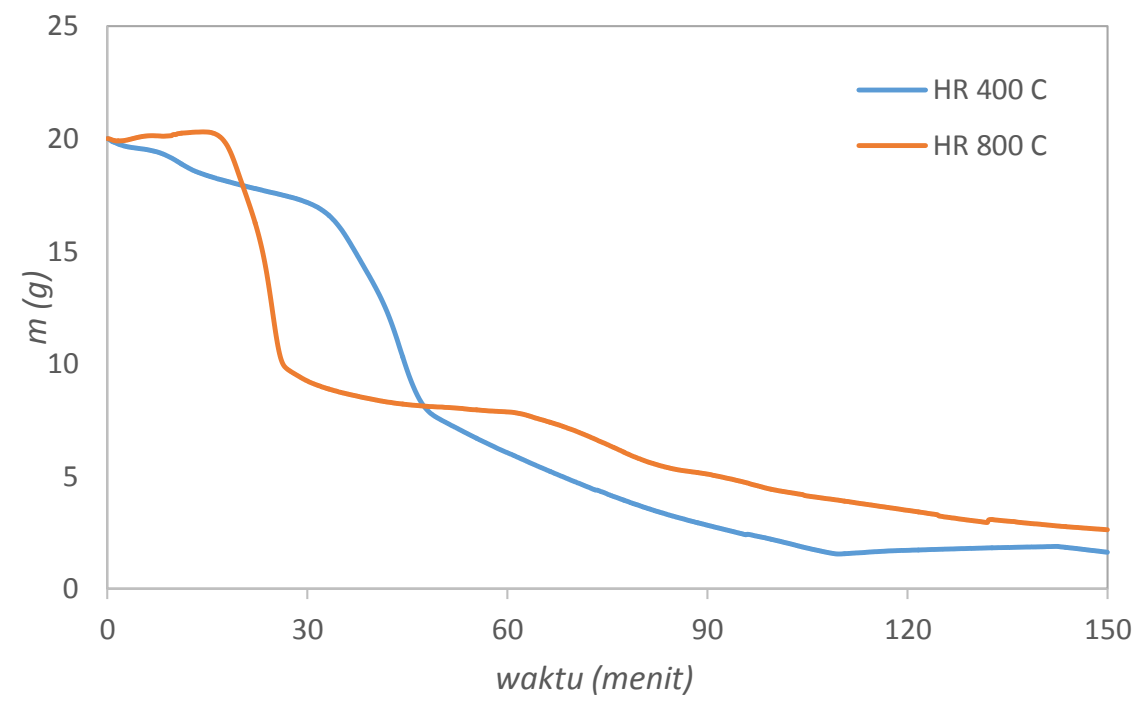

Gambar 2 Perubahan masa kayu mahoni selama proses pirolisis

Kayu mahoni merupakan salah satu jenis kayu hardwood, dimana dekomposisi termal terjadi dimulai pada temperatur di atas $350^{\circ} \mathrm{C}$ untuk selulosa hingga di atas $600^{\circ} \mathrm{C}$ untuk senyawa keras lignin yang cukup sulit terdekomposisi [9]. Hal ini dapat dilihat Gambar 3 yang menunjukkan perubahan temperatur selama proses. Bila dihubungkan antara Gambar 2 dan 3, maka rata-rata dekompisisi senyawa biomasa dapat dilihat terjadi pada menit ke-30 untuk selulosa dan menit ke-120 untuk dekompisisi lignin pada heating rate $400^{\circ} \mathrm{C} / \mathrm{jam}$. Hemiselulosa akan terdekomposisi pada temperatur pirolisis $473-553 \mathrm{~K}$, sedangkan selulosa akan terdekomposisi pada temperatur 523-623 K dan lignin akan terdekomposisi pada temperatur 453-lebih1000 K [10]. Pada temperatur tersebut masing-masing unsur akan terdekomposisi menjadi char, bio-oil, dan gas. Penelitian lain menyatakan perbedaan temperatur dekomposisi senyawa-senyawa biomasa tersebut [7-8], tetapi secara global dapat disimpulkan bahwa rata-rata dekomposisi senyawa akan terjadi mulai temperatur $600^{\circ} \mathrm{C}$. Temperatur dekomposisi lignin akan terjadi pada temperatur yang lebih tinggi. 


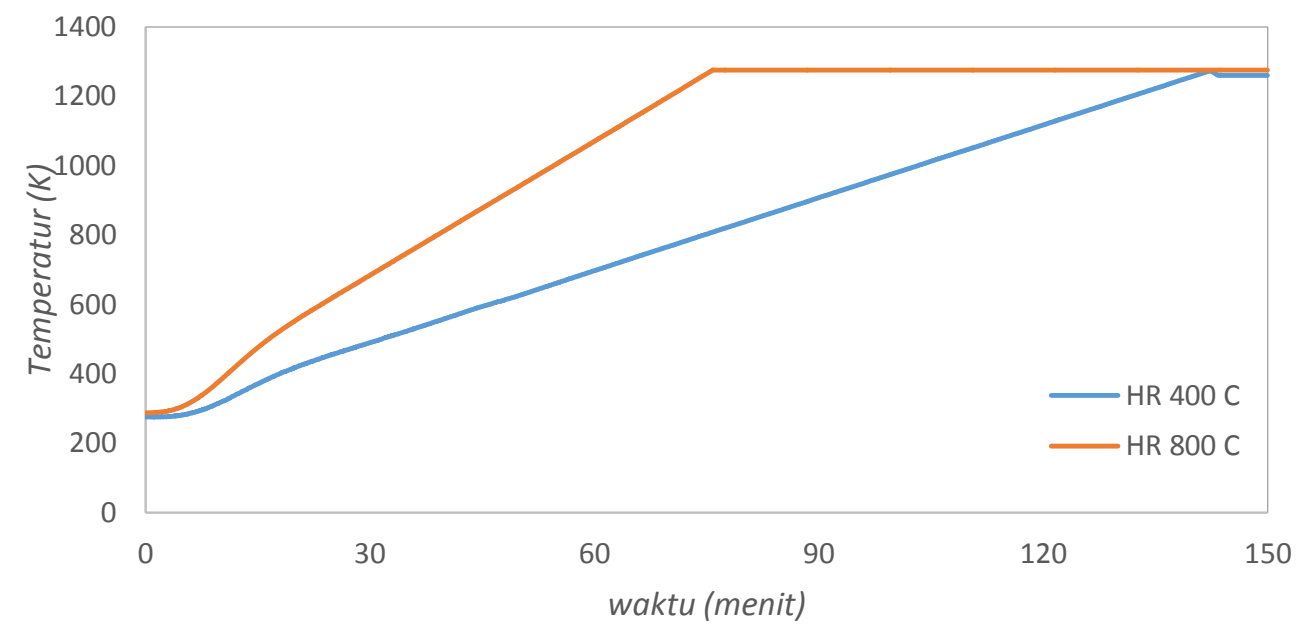

Gambar 3 Perubahan temperatur selama proses pirolisis

Masa kayu mahoni akan berkurang seiring dengan adanya peningkatan temperatur. Hal ini disebabkan panas akan mendekomposisi senyawa-senyawa biomasa yang berwujud padat menjadi senyawa-senyawa cair dan gas. Pada Gambar 2 dapat diamati bahwa terjadi perbedaan penurunan massa selama pirolisis pada heating rate yang berbeda. Pada heating rate $400^{\circ} \mathrm{C} / \mathrm{jam}$, terlihat penurunan masa yang tidak terlalu tajam, Berbeda dengan kondisi tersebut, pada heating rate $800^{\circ} \mathrm{C} /$ jam penurunan masa terjadi sangat signifikan. yang menurun dengan sangat tajam. Pada kondisi heating rate $800^{\circ} \mathrm{C} / \mathrm{jam}$, penurunan masa juga terjadi lebih cepat bila dibandingkan dengan heating rate $400^{\circ} \mathrm{C} / \mathrm{jam}$. Hal tersebut terjadi karena dengan semakin tinggi heating rate maka akselerasi energi panas yang diberikan untuk memecah senyawa-senyawa biomasa lebih besar menyebabkan laju dekomposisi serbuk kayu mahoni akan semakin cepat dan besar pula. Selain itu, kenaikan suhu pada furnace yang terjadi akan semakin cepat, sehingga kandungan hemiselulosa, selulosa, dan lignin yang terdekomposisi akan semakin cepat pula.

Pada awal pemanasan terjadi fase penguapan air yang masih terkandung pada serbuk kayu. Kemudian setelah mencapai temperatur 473-653 K pada menit ke-30 hemiselulosa mulai terdekomposisi dan selulosa baru akan mulai terdekomposisi begitu juga dengan lignin yang baru akan mulai terdekomposisi hal ini menyebabkan grafik menurun. Kemudian pada temperatur 523-653 K pada menit ke-40, selulosa sudah mulai terdekomposisi dan hemiselulosa juga sudah dalam tahap dekomposisi kemudian di detik ini lignin baru mulai terdekomposisi. Dekomposisi masing-masing senyawa tersebut menyebabkan biomasa yang berwujud padat terurai menjadi tar (cair) dan gas. Akibatnya adalah pengecilan ukuran biomasa solid (kayu) yang lambat laun akan menjadi char (solid yields). Hal inilah yang menyebabkan grafik penurunan masa mengalami penurunan. Apalagi bila selulosa, hemiselulosa, dan lignin terurai bersama, maka biomasa akan mengalami penurunan secara signifikan yang terjadi pada temperatur 453-1173 K pada menit ke-100 semua unsur-unsur serbuk kayu yaitu hemiselulosa, selulosa, dan lignin terdekomposisi secara bersamaan. Pada rentang waktu inilah terjadi penurunan grafik secara signifikan kemudian laju penurunan massa mulai menurun karena semua kandungan sudah terdekomposisi tersisa lignin yang masih terdekomposisi karena lignin memerlukan suhu yang tinggi untuk terdekomposisi.

Pada heating rate $800^{\circ} \mathrm{C} / \mathrm{jam}$, belum terlihat pengurangan massa hingga menit ke-15. Namun, terjadi penurunan massa yang sangat tajam pada menit ke-15 hingga 25, yaitu pada temperatur 503-653 K karena unsur biomasa : hemiselulosa, selulosa, dan lignin terdekomposisi secara bersamaan. Meskipun pada fase ini hemiselulosa dan selulosa terdekomposisi secara menyeluruh dan bersamaan, sedangkan lignin masih membutuhkan waktu lebih lama untuk terurai. Karena dibutuhkan waktu yang lebih lama untuk lignin inilah yang menyebabkan perubahan penurunan massa menjadi lebih lambat.

\subsection{Perubahan masa setiap waktu (DTG)}

Selanjutnya, dari grafik perubahan masa kayu mahoni selama proses pirolisis yang terdapat pada Gambar 2, dihitung pula perubahan masanya setiap waktu yang diplot pada Gambar 4. Grafik tersebut merupakan penurunan massa persatuan waktu yang bisa juga disebut dengan DTG (Derivative thermogravimetric $(\mathrm{dm} / \mathrm{dt})$ ), pada heating rate $400^{\circ} \mathrm{C} / \mathrm{jam}$ dan $800^{\circ} \mathrm{C} / \mathrm{jam}$ dengan menggunakan serbuk kayu mahoni seberat $20 \mathrm{mg}$. 


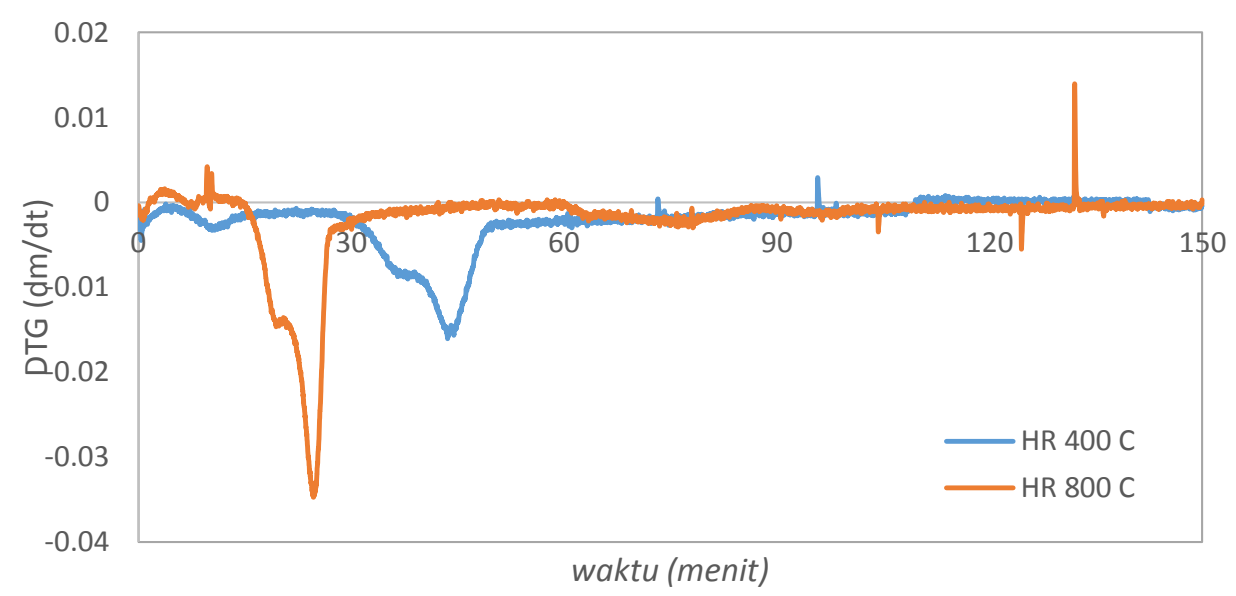

Gambar 4 Perubahan masa setiap waktu (DTG) pada proses pirolisis pada heating rate $400{ }^{\circ} \mathrm{C} / \mathrm{jam}$ dan $800^{\circ} \mathrm{C} / \mathrm{jam}$

Dari grafik tersebut diatas dapat dilihat bahwa terlihat heating rate $400^{\circ} \mathrm{C} / \mathrm{jam}$ memiliki puncak grafik yang lebih rendah dibandingkan dengan puncak grafik yang dimiliki oleh heating rate $800^{\circ} \mathrm{C} / \mathrm{jam}$. Selain itu, pencapaian puncak heating rate $400^{\circ} \mathrm{C} / \mathrm{jam}$ memiliki waktu yang lebih lama bila dibandingkan dengan heating rate $800^{\circ} \mathrm{C} / \mathrm{jam}$. Semakin besar heating rate, maka DTG akan memiliki puncak grafik yang semakin ekstrim. Apabika heating rate semakin besar, maka senyawa-senyawa serbuk kayu yang terdekomposisi akan semakin tinggi juga. Hal ini akan menyebabkan puncak grafik DTG juga akan semakin ekstrim. Peningkatan heating rate nampaknya akan meningkatkan perubahan temperatur di setiap tahap, yang mungkin disebabkan oleh proses perpindahan panas. Ada 3 (tiga) tahap range temperatur yang terjadi; tahap I ini adalah tahap temperatur dimana terjadi penurunan masa kayu untuk yang pertama kalinya, dilanjutkan tahap II yaitu tahap puncak penurunan masa maksimum. Sedangkan tahap terakhir adalah tempat penurunan masa yang nilainya hamper sama seperti tahap I. Seperti yang sudah diketahui bahwa pirolisis terbagi menjadi 3 bagian, yaitu penguapan air, pirolisis aktif dan pirolisis pasif, yaitu saat pirolisis mencapai kondisi equlibrium dan sudah tidak terjadi dekomposisi lagi.

Heating rate $400^{\circ} \mathrm{C} / \mathrm{jam}$ memiliki puncak grafik lebih rendah dan waktu yang lebih lama untuk mencapai puncak grafik, karena memliki laju reaksi yang lambat. Di tahap I, untuk proses penguapan memerlukan waktu 0-8 menit sampai terjadi evaporasi air. Untuk tahap selanjutnya, proses pirolisis masuk ke dalam fase pirolisis aktif dimana posisi pirolisis aktif berada pada 15-50 menit dan pada waktu selanjutnya adalah tahap perubahan masa tiap waktunya mengalami penurunan yang menandakan bahwa pirolisis memasuki tahap III yaitu pirolisis pasif. Kemudian, heating rate $800^{\circ} \mathrm{C} / \mathrm{jam}$ memiliki puncak grafik lebih tinggi dibanding $400^{\circ} \mathrm{C} / \mathrm{jam}$ dan memiliki waktu yang lebih cepat untuk mencapai puncak grafik DTG. Hal ini dikarenakan pada heating rate $800^{\circ} \mathrm{C} / \mathrm{jam}$, laju perpindahan panas yang cepat memaksa biomasa untuk terdekomposisi, sehingga proses pirolisis memiliki laju reaksi yang lebih cepat. Untuk proses penguapan pada heating rate ini memerlukan waktu 5 menit untuk evaporasi air. Selanjutnya masuk dalam pirolisis aktif pada menit ke-15 hingga 25, dilanjutkan ke tahap pirolisis pasif dimana lignin sudah memasuki fase terdekomposisi yang disertai dengan penurunan grafik pada menit ke 25 hingga kemudian grafik berada pada konidisi equilibrium yang dimulai pada menit ke-50.

Di tahap II yaitu saat terjadi pirolisis aktif, terjadi 2 puncak perubahan masa baik pada heating rate $400^{\circ} \mathrm{C} / \mathrm{jam}$ dan $800^{\circ} \mathrm{C} / \mathrm{jam}$. Pada heating rate rendah, puncak pertama terjadi pada menit ke-35 sedangkan puncak kedua terjadi pada menit ke-50. Untuk heating rate tinggi, puncak pertama terjadi lebih cepat pada menit ke-17, sementara puancak kedua pada menit ke-25. Hal ini dikarenakan dekompisisi senyawa biomasa terjadi pada 2 tahap, dimana tahap 1 terjadi dekomposisi hemiselulosa dan dilanjutkan pada tahap II dimana terjadi dekomposisi selulosa. Setelah puncak ke-2 tercapai, secara bersamaan, baik selulosa maupun hemiselulosa akan terdekomposisi dahulu. Sedangkan lignin akan terdekomposisi pada akhir puncak kedua dan pada tahap 3.setelah memasuki tahap pirolisis pasif dengan menurunnya grafik DTG.

Hal ini terlihat bahwa semakin tinggi heating rate yang dipakai maka puncak grafik juga akan semakin tinggi serta waktu penguapan air dan dekomposisi unsur-unsur serbuk kayu akan semakin cepat, dimana bagian awal dari pirolisis adalah tahap penguapan air dilanjutkan tahap pirolisis aktif dimana hemiselulosa dan selulosa sudah mulai terdekomposisi, dan kemudian lignin terdekomposisi diantara tahap pirolisis aktif dan 
pirolisis pasif.

\subsection{Perubahan temperatur pirolisis setiap waktu (DTA)}

Differential thermal analysis (DTA) adalah perubahan temperatur selama proses terhadap perubahan waktu yang terjadi pada proses pirolisis. Perubahan termal menunjukkan kecenderungan yang berbeda antara heating rate $400^{\circ} \mathrm{C} / \mathrm{jam}$ dan $800^{\circ} \mathrm{C} / \mathrm{jam}$. Puncak DTA menunjukkan waktu yang berbeda terlihat pada Gambar 5 yang menunjukkan grafik distribusi temperatur selama proses. Pada heating rate $400^{\circ} \mathrm{C} / \mathrm{jam}$, DTA mengalami penurunan dan mencapai puncak pada menit ke-140. Sedangkan heating rate $800^{\circ} \mathrm{C} / \mathrm{jam}$ mencapai puncaknya lebih cepat dibanding $400^{\circ} \mathrm{C} / \mathrm{jam}$ di kisaran menit ke-75. Hal ini sebanding dengan besarnya laju pemanasan, yaitu semakin besar laju pemanasan, maka akselerasi pencapaian panas akan lebih cepat terjadi dan akan mengakibatkan pola dekomposisi kayu mahoni, seperti terlihat pada Gambar 2 dan 4. Hal ini dikarenakan perbedaan kecepatan panas dalam mengurai senyawa-senyawa biomasa dengan ilustrasi selulosa yang terlihat pada Gambar 6. Heating rate (laju pemanasan) merupakan parameter utama untuk mendapatkan perbedaan antara proses pirolisis yang lambat $\left(400^{\circ} \mathrm{C} / \mathrm{jam}\right.$ dan pirolisis yang cepat $\left(800^{\circ} \mathrm{C} / \mathrm{jam}\right)$. Parameter ini, dengan kata lain, adalah waktu yang diperlukan untuk mencapai suhu reaksi biomassa. Laju pemanasan yang tinggi mendorong reaksi depolimerisasi selulosa dan hemiselulosa serta meminimalkan waktu tinggal volatile matter di dalam partikel biomasa dan juga meminimalisir reaksi sekunder. Ini juga dapat mendekomposisi senyawa-senyawa volatile. Selain itu, pelepasan gas yang dapat dikondensasi berlangsung dengan cepat, sehingga mencapai hasil tinggi dari bio-oil dan produksi arang terendah.

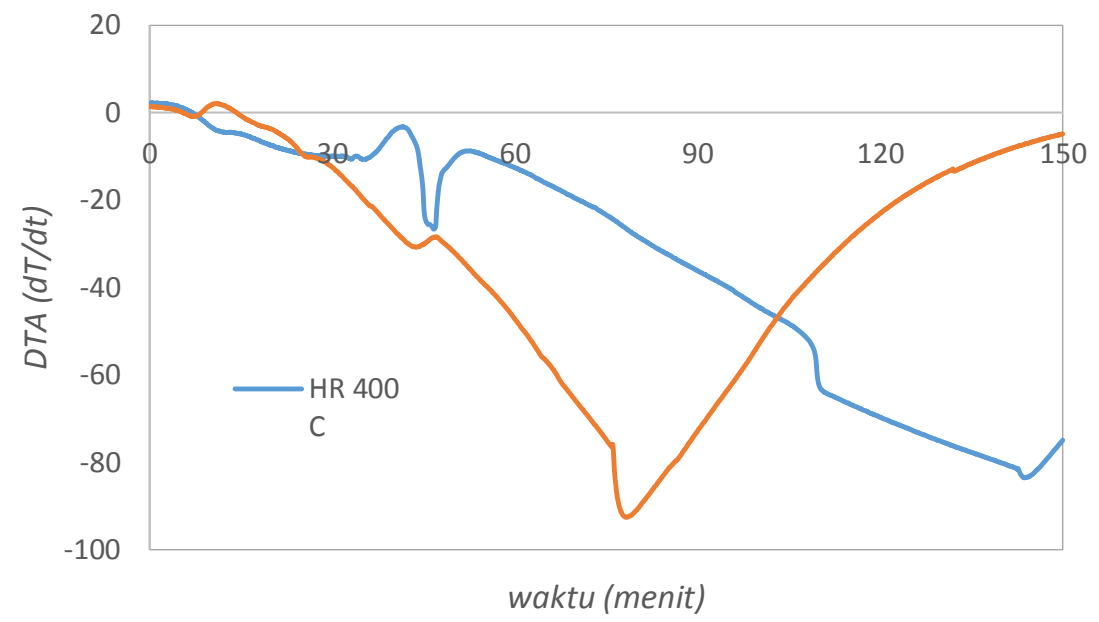

Gambar 5 Perubahan termal setiap waktu selama proses pirolisis pada heating rate $400^{\circ} \mathrm{C} / \mathrm{jam}$ dan $800^{\circ} \mathrm{C} / \mathrm{jam}$

Chaiwat dkk [11] telah meneliti serangkaian reaksi kompetitif antara depolimerisasi selulosa, seperti yang ditunjukkan pada Gambar 6. Hasil penelitian ini juga didukung oleh Agarwal dkk [12] yang, melalui simulasi numerik, mempelajari perubahan yang mempengaruhi selulosa selama proses pirolisis dengan heating rate yang tinggi. Ternyata ada perubahan ikatan tipe hidrogen dalam struktur selulosa. Temperatur rendah dan laju pemanasan yang rendah mendorong ikatan hidrogen intra-rantai dari gugus fungsi selulosa, meningkatkan kemungkinan dekomposisi untuk menghasilkan reaksi dehidrasi evaporasi. Untuk laju pemanasan yang tinggi, ikatan hidrogen antar-rantai lebih kuat untuk mencapai pemisahan yang lebih besar antara molekul selulosa dan dengan demikian mengurangi kemungkinan tumbukan yang memfasilitasi reaksi dehidrasi. 


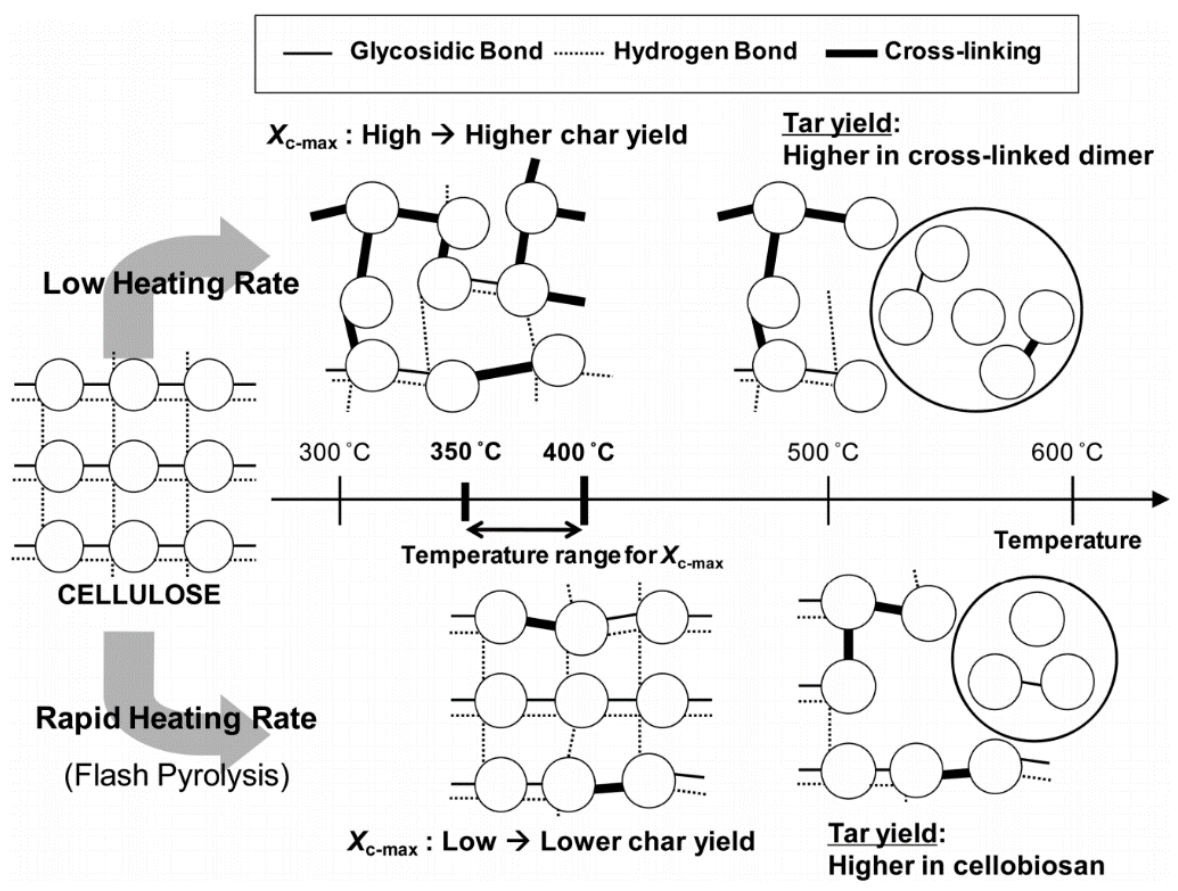

Gambar 6 Dekomposisi senyawa biomasa akibat perbedaan laju pemanasan Sumber : [11]

Sehingga, laju pemanasan (heating rate) ini sangat mempengaruhi laju dekomposisi yang terjadi sehingga akan mempengaruhi proses penguraian unsur-unsur serbuk kayu mahoni. Bila dihubungkan dengan Gambar 2 maka besarnya laju perubahan temperatur akan memberikan efek terhadap perubahan masa kayu mahoni, dimana puncak perubahan masa (DTG) dan perubahan temperatur (DTA) akan mencapai puncak pada waktu yang hampir sama. Pada grafik heating rate $800^{\circ} \mathrm{C} / \mathrm{jam}$, terlihat proses laju pemanasan pada biomasa terjadi lebih cepat untuk mencapai temperatur $1000^{\circ} \mathrm{C}$ dibanding $400^{\circ} \mathrm{C} / j a m$. Laju pemanasan yang cepat ini terbukti akan mempengaruhi laju dekomposisi yang terjadi sehingga proses penguraian unsur-unsur serbuk kayu mahoni juga terjadi secara cepat.

Bila dihubungkan dengan penelitian terdahulu dan pada real pilot plat pirolisis [13], besarnya heating rate akan mempercepat pembentukan produk pirolisis, terutama produk tar dan gas. Pada pengujian TGA, tidak dapat dianalisa besarnya produk (yields) pirolisis. Perubahan masa yang terjadi pada gambar 2 dan 4 adalah perubahan solid yields yaitu perubahan masa biomasa selama proses. Oleh karenanya, perubahan kayu menjadi char tidak dapat terdeteksi pada menit keberapa, hanya dapat dilihat saat akhir proses pirolisis, solid yield sudah berupa char. Meskipun begitu, dapat diprediksi, bahwa mekanisme penguraian biomasa pada proses pirolisis sejalan dengan Gambar 6 sesuai dengan hasil data pada penelitian ini dan pada penelitian-penelitian sebelumnya [1-13]. Contohnya pada selulosa saja. Pada heating rate yang rendah, dekomposisi selulosa selama pirolisis relatif lambat. Hal ini dikarenakan peningkatan temperatur berjalan lambat sehingga evaporasi air terjadi pada periode reaksi yang lebih lama. Evaporasi akan menghasilkan air dan beberapa senyawa yang terjadi secara bersamaan dengan reaksi glycosidic untuk menghasilkan tar selama pirolisis. Gugus hidroksil dalam selulosa dikonversi menjadi air, char (Xc), dan tar (Xt) [11]. Untuk analisis cross-linking pada tingkat pemanasan rendah, reaksi dapat terjadi hingga sekitar $360^{\circ} \mathrm{C}$ ketika produk char mencapai maksimum, sementara tar yang terhubung tampaknya dirilis di atas $360^{\circ} \mathrm{C}$. Untuk pembentukan tar, dimer cross-linked dapat diamati untuk pirolisis lambat, sedangkan hasil tinggi cellobiosan dapat diperoleh tanpa dimer crosslinked di heating rate tinggi (flash pyrolysis). Karena flash pirolisis hampir tidak menghasilkan cross-linked volatile, maka sebagian besar produk melepaskan air oleh fermentasi untuk menghasilkan gas ringan, dengan produk char yang rendah. 


\subsection{Efek heating rate pada persamaan laju reaksi pada proses pirolisis (kinetic rate solid yields product)}

Dari grafik perubahan masa dan temperatur pada Gambar 2 dan 3 , maka dapat dibuat Arrhenius plot yang menghubungkan antara $\ln k$ dan $1 / T$, yang digambarkan oleh Gambar 7 dan 8 . Sebelum memplot $\ln k$ dan I/T dalam Arhenius plot, terlebih dahulu dicari nilai $k$ yang didapatkan dari Gambar 7 dengan menggunakan Persamaan 1.

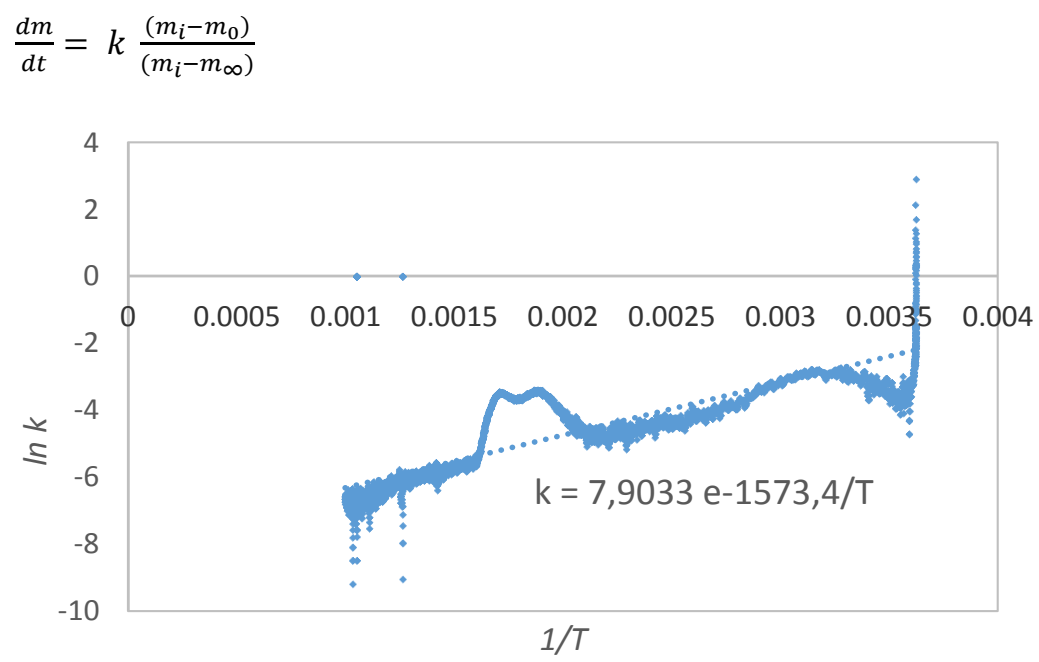

Gambar 7 Arrhenius plot untuk mencari persamaan laju reaksi proses pirolisis dengan menghitung Kinetic rate solid yields pada heating rate $400^{\circ} \mathrm{C} / \mathrm{jam}$

Dimana $d m$ merupakan selisih masa sebelum $i$ dan masa $i$, begitu juga $d t$ adalah waktu sebelum i dan waktu ke-i. Selanjutnya, nilai $k$ diplot dalam ke dalam grafik Arrhenius plot dibuat dalam bentuk fungsi $\ln k$ dan $1 / T$, karena hal ini untuk mendapatkan konstanta persamaan perubahan masa seperti pada Persamaan 2 dalam bentuk linier.

$$
k=k_{0} \exp ^{\left(\frac{-E}{R T}\right)}
$$

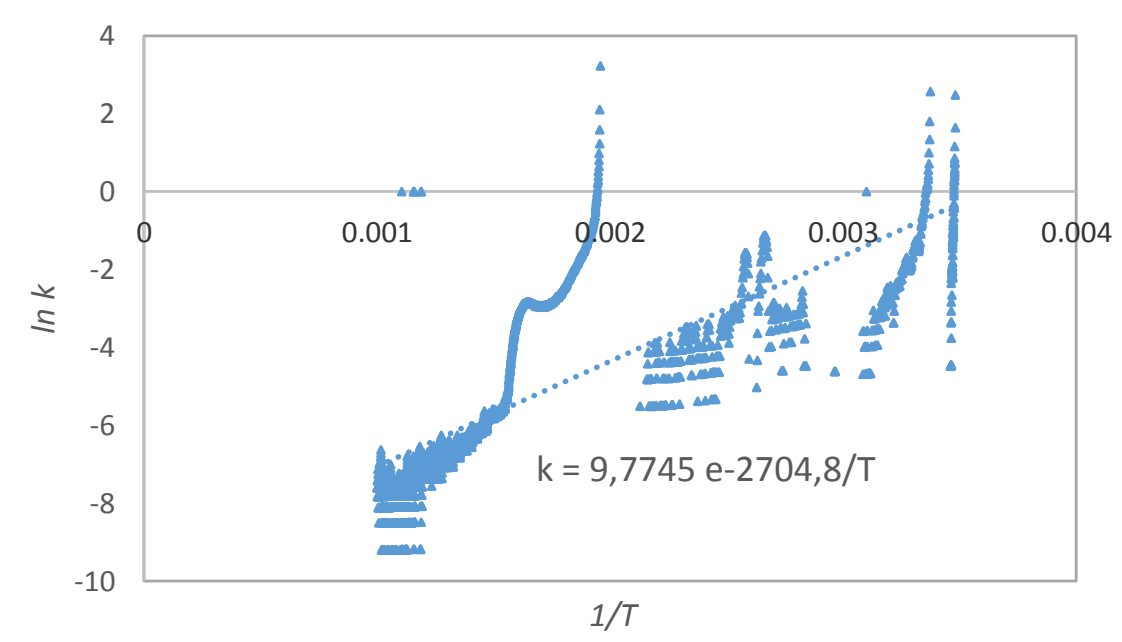

Gambar 8 Arrhenius plot untuk mencari persamaan laju reaksi proses pirolisis dengan menghitung kinetic rate solid yields pada heating rate $800^{\circ} \mathrm{C} / \mathrm{jam}$ 
Kedua grafik yang tergambar dalam Gambar 7 dan 8 adalah Arrhenius plot untuk heating rate rendah $\left(400^{\circ} \mathrm{C} / \mathrm{jam}\right)$ dan heating rate tinggi $\left(800^{\circ} \mathrm{C} / \mathrm{jam}\right)$. Dari kedua grafik tersebut, didapatkan persamaan kinetik rate untuk heating rate rendah yang dirumuskan dengan Persamaan 3 dan heating rate tinggi pada Persamaan 4

$$
\begin{aligned}
& k_{1}=7.9033 \exp ^{-1573.4 / \mathrm{T}} 3 \\
& k_{2}=9.7745 \exp ^{-2704.8 / \mathrm{T}}
\end{aligned}
$$

Dengan begitu dari persaman kinetik rate pada Persamaan 3 dan 4 di atas didapatkan energi aktivasi dan nilai pre-exponensial factor. Energi aktivasi solid yields pada heating rate $400^{\circ} \mathrm{C} / \mathrm{jam}$ adalah sebesar $1573.4 /(\mathrm{RT})$ dan pre-exponensial factor yaitu 7.9033 . Sedangkan pada heating rate $800^{\circ} \mathrm{C} / \mathrm{jam}$ memiliki energi aktivasi -2704.8/(RT) dengan pre-exponensial factor sebesar 9.7745.

Dari persamaan tersebut kita dapat mendapatkan hasil nilai kinetic rate dengan memasukan nilai $\mathrm{R}$ (konstanta gas) dan $\mathrm{T}$ ( temperatur) di setiap waktu sehingga didapatkan nilai kinetic rate pada heating rate $400^{\circ} \mathrm{C} / \mathrm{jam}$ yang lebih kecil dibandingkan nilai kinetic rate pada heating rate $800^{\circ} \mathrm{C} / \mathrm{jam}$.

Selanjutnya, dari persaman kinetik rate yang didapat, perubahan masa solid yield teoritis selama pirolisis dapat diprediksi dengan menggunakan Persamaan 1 kembali dan digambarkan pada Gambar 8 dan 9. Ternyata, dalam validasi perubahan masa aktual dan teoritis ada perbedaan yang cukup signifikan, dikarenakan penggunaan model reaksi pada penelitian yang hanya menggunakan one-model reaction rate, dimana persamaan kinetic rate diregresi menjadi 1 persamaan linier seperti yang terlihat pada Gambar 7 dan 8. Padahal, di tahap II pada grafik DTG (Gambar 5) dan TGA (Gambar 5) ada 2 puncak perubahan masa dan temperatur yang perlu dianalisa lagi pada penelitian berikutnya dengan menggunakan 2-3 model reaksi seperti yang sudah dilakukan oleh Widya dkk [6].

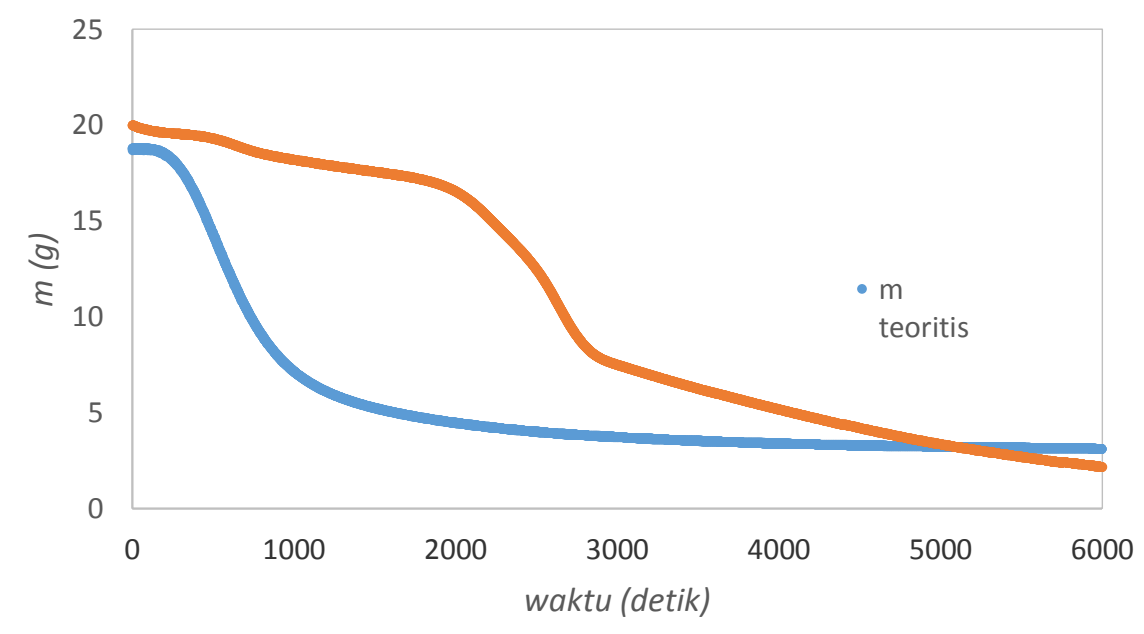

Gambar 9 Validasi perubahan masa kayu mahoni untuk hasil pengujian TGA (masa aktual) dan hasil perhitungan dengan menggunakan persamaan kinetika reaksi (masa teoritis) pada heating rate $400^{\circ} \mathrm{C} / \mathrm{jam}$

Pada Gambar 8, terlihat bahwa masa aktual menunjukkan penurunan yang lambat seiring dengan laju pemanasan sebesar $400^{\circ} \mathrm{C} / \mathrm{jam}$, dengan penurunan masa yang tajam terjadi setelah detik ke-2000 (sekitar menit ke-35). Selanjutnya pada detik ke-3000 (menit ke-50), terjadi penurunan biomasa yang relatif rendah hingga pada akhir pirolisis. Pada masa aktual ini, kondisi equilibrium belum tercapai, dimana seharusnya pada dekomposisi lignin, kondisi equilibrium sudah tercapai. Pada validasi masa teoritis hasil perhitungan kinetik rate, kondisi equilibrium sudah tercapai mulai detik ke-3000, tetapi dekomposisi biomasa terjadi sangat cepat pada detik ke-250. Sedangkan pada Gambar 9, hasil validasi antara masa aktual dan masa teoritis menunjukkan hasil yang lebih match pada keduanya dibanding Gambar 7. Dekomposisi biomasa yang ditunjukkan oleh penurunan masa yang ekstrim terjadi lebih cepat pada hasil perhitungan (masa teoritis) dibanding hasil eksperimen. Pada heating rate tinggi, 
seharusnya dekomposisi biomasa terjadi secara cepat dengan hasil char yang rendah dan produk gas serta tar yang sengat besar. Sehingga masa teoritis menunjukkan hasil yang lebih dapat diterima dibanding dengan hasil eksperimen. Apabila dibandingkan masa teoritis antara heating rate rendah dan tinggi, penurunan masa yang menunjukkan dekomposisi biomasa dicapai lebih dulu oleh heating rate tinggi, yaitu pada kisaran detik ke-300, 200 detik lebih cepat dibanding heating rate rendah. Oleh karena itu, meskipun ada selisih hasil antara masa teoritis dan masa aktual, namun hasil perhitungan teoritis dapat diterima dengan menggunakan persamaan kinetik rate yang sudah didapatkan dari paramater-parameter analisa data TGA.

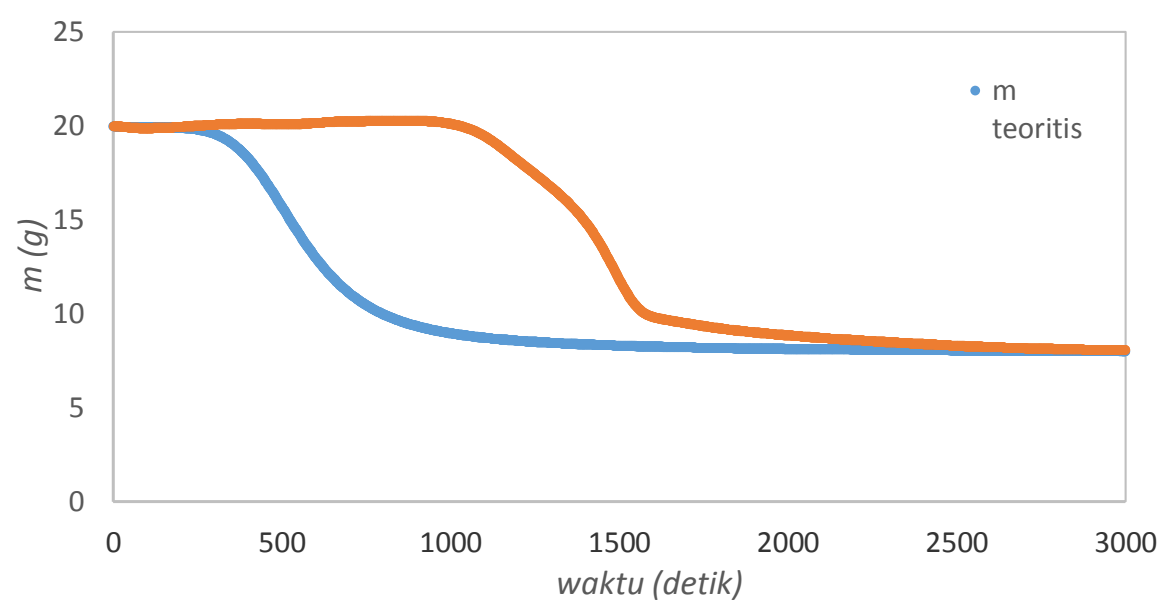

Gambar 10 Validasi perubahan masa kayu mahoni untuk hasil pengujian TGA (masa aktual) dan hasil perhitungan dengan menggunakan persamaan kinetika reaksi (masa teoritis) pada heating rate $800^{\circ} \mathrm{C} / \mathrm{jam}$

\section{KESIMPULAN}

Dapat disimpulkan bahwa laju pemanasan (heating rate) sangat mempengaruhi laju dekomposisi yang terjadi sehingga akan mempengaruhi proses penguraian unsur-unsur serbuk kayu mahoni :

1. pengurangan massa biomasa pada heating rate $400^{\circ} \mathrm{C} / \mathrm{jam}$ lebih lambat jika dibandingkan dengan menggunakan heating rate $800^{\circ} \mathrm{C} / j a m$ karena kemampuan penyebaran panas secara konduksi dalam furnace dan temperatur maksimum akan lebih cepat tercapai sehingga laju dekomposisi senyawasenyawa seperti hemiselulosa, selulosa dan lignin akan semakin cepat terdekomposisi

2. Pada DTA, heating rate $400^{\circ} \mathrm{C} / \mathrm{jam}$ memiliki puncak grafik yang rendah dan memiliki waktu yang lebih lama untuk mencapai puncak tertinggi, bila dibandingkan dengan puncak grafik yang dimiliki oleh heating rate $800^{\circ} \mathrm{C} / \mathrm{jam}$

3. Besarnya laju perubahan temperatur akan memberikan efek terhadap perubahan masa kayu mahoni, dimana puncak perubahan masa (DTG) dan perubahan temperatur (DTA) akan mencapai puncak pada waktu yang bersamaan.

4. Ada selisih hasil antara masa teoritis dan masa aktual karena regresi linier persamaan kinetik rate mnggunakan one model reaction. Meskipun begitu, hasil perhitungan teoritis dapat diterima dengan menggunakan persamaan kinetik rate yang sudah didapatkan dari paramater-parameter analisa data TGA.

\section{PERNYATAAN TERIMAKASIH}

Terimakasih penulis ucapkan kepada Arbianto Nurasri Sudarmawan yang telah membantu penulis dalam pengambilan data, atas segala kerja keras, dan sharing knowledge selama penelitian ini berlangsung. Terimakasih pula penulis ucapkan kepada Dekan Fakultas Teknik Universitas Brawijaya atas dukungan dana penelitian DIPA 2018, sehingga penelitian ini dapat berjalan dengan lancar sehingga penulisan jurnal ini dapat terselesaikan dengan baik.

\section{DAFTAR PUSTAKA}

[1] BO WANG, FANFAN XU, PEIJIE ZONG, JINHONG ZHANG, YUANYU TIAN, YINGYUN QIAO, "Effects of heating rate on fast pyrolysis behavior and product distribution of Jerusalem artichoke stalk 
by using TG-FTIR and Py-GC/MS”, Renewable Energy, V. 132, pp 486-496, March 2019

[2] MOHAMMAD-SAEED SAFDARI, ELHAM AMINI, DAVID R. WEISE, THOMAS H. FLETCHER, "Heating rate and temperature effects on pyrolysis products from live wildland fuels", Fuel, V. 242, pp 295-304, 15 April 2019

[3] AYHAN DEMIRBAS, "Pyrolysis of ground beech wood in irregular heating rate conditions", Journal of Analytical and Applied Pyrolysis, V. 73, n. 1, pp 39-43, March 2005

[4] TOSHIYUKI IWASAKI, SEIICHI SUZUKI, TOSHINORI KOJIMA, "Influence of Biomass Pyrolysis Temperature, Heating Rate and Type of Biomass on Produced Char in a Fluidized Bed Reactor", Energy and Environment Research, V. 4, n. 2; 2014

[5] JIANQIAO WANG, BOXIONG SHEN, DONGRUI KANG, PENG YUAN, CHUNFEI WU, "Investigate the interactions between biomass components during pyrolysis using in-situ DRIFTS and TGA", Chemical Engineering Science, V. 195, pp 767-776, 23 February 2019

[6] WIJAYANTI, W., TANOUE, K, SUETOMI, "Rule of thumb for simulating biomass pyrolysis in packed bed reactor", 11th AIChE Annual Meeting, Boston University, 16-21 October, 2011

[7] RH MUHDHOR, W WIJAYANTI, K ANAM, "Pengaruh Temperatur Pirolisis Terhadap Kualitas Dan Kinetic Rate Char Hasil Pirolisis Serbuk Kayu Mahoni”, Jurnal Jurusan Teknik Mesin, Fakultas Teknik, Universitas Brawijaya, 2013

[8] W WIJAYANTI, K TANOUE, "Char formation and gas products of woody biomass pyrolysis", Energy Procedia 32, pp. 145-152, 2013

[9] JORGE IVÁN MONTOYA, FARID CHEJNE-JANNA, MANUEL GARCIA-PÉREZ, "Fast pyrolysis of biomass: A review of relevant aspects. Part I: Parametric study (Pirólisis rápida de biomasas: Una revisión de los aspectos relevantes. Parte I: Estudio paramétrico)", DYNA, V. 82, n. 192, pp. 239-248, 2015

[10] KATARZYNA SLOPIECKA, PIETRO BARTOCCI, FRANCESCO FANTOZZI, "Thermogravimetric analysis and Kinetic study of poplar wood pyrolisis", Applied Energy, V. 97, pp 491-497, September 2012

[11] CHAIWAT, W., HASEGAWA, I., TANI, T., SUNAGAWA, K. and MAE, K., "Analysis of cross-linking behavior during pyrolysis of cellulose for elucidating reaction pathway", Energy \& Fuels, V. 23, n. 12, pp. 5765-5772, 2009

[12] AGARWAL, V., DAUENHAUER, P.J., HUBER, G.W. and AUERBACH, S.M., "Ab initio dynamics of cellulose pyrolysis: Nascent decomposition pathways at 327 and $600{ }^{\circ} \mathrm{C}$ ", J. Am. Chem. Soc., V. 134 (36), pp. 14958-14972, 2012

[13] F MAJEDI, W WIJAYANTI, N HAMIDI, "Parameter Kinetik Char Hasil Pirolisis Serbuk Kayu Mahoni (Switenia Macrophylla) dengan Variasi Heating Rate dan 1 Temperatur", Rekayasa Mesin 6 (1), 1-7, 2015 